IRSH 60 (2015), Special Issue, pp. 275-293 doi:I0.10 I 7/S00208 590 I 500040 I

(C) 2015 Internationaal Instituut voor Sociale Geschiedenis

\title{
Integration through Sports? Polish Migrants in the Ruhr, Germany
}

\author{
DIETHELM B LECKING \\ Institut für Sport und Sportwissenschaft, \\ Albert-Ludwigs-Universität Freiburg \\ Schwarzwaldstr. I75, 79II7 Freiburg, Germany
}

E-mail: blecking@aol.com

\begin{abstract}
Sport, and football in particular, is described in socio-political discourse as an effective way to integrate immigrants. This thesis will be tested by means of a case study examining Polish migration to the mining areas of the Ruhr from the i 870 s. It will be shown that, up until World War I, the sport participated in by Polish miners served, in contrast, as a means of nationalization, ethnicizing, and as an aid to furthering Polish ethnic identity. Only during the Weimar Republic were football clubs in the Ruhr actually used as a vehicle for integration and assimilation for males among the Polish minority. After World War II, memories of these footballers from among the Polish minority were either repressed or reduced to folklore. Based on this historical case study, sport appears in principle to be ambivalent between its ability to form "we" groups and the building of bridges between nationalities.
\end{abstract}

Following a decision by the EU Commission, almost 170 years of coalmining in Germany will come to an end in 2018 when the last five pits in the Saarland and the Ruhr cease operations. ${ }^{\mathrm{I}}$ In an attempt to draw up a preliminary balance sheet of its social and cultural history, a conference on "Underground Worlds" in Dortmund in May 20I4 brought together a broad spectrum of studies on the cultures of mining and miners. Speakers addressed themes such as the pictorial arts, literature and film, and gender relations. ${ }^{2}$ In their reflections on miners' cultures, however, the more "evident" topics of migration, leisure, and sport were scarcely mentioned. This is remarkable, as sports, and football in particular, have enjoyed an outstanding status in mining cultures all over the world, both for players and spectators. Also, migration processes were of paramount importance in the development of coalfields worldwide, including the Ruhr, where Polish

I. "EU lässt Subventionen bis 2018 zu”, Frankfurter Allgemeine Zeitung, 8 December 2010.

2. See Arne Hordt's report on the conference "Welt unter Tage. Neue Perspektiven für die Bergbaukultur am Ende des Bergbaus", Dortmund, 23-24 May 20I4, at http://hsozkult. geschichte.hu-berlin.de/tagungsberichte/id=5457; last accessed i 5 July 20 I 5 . 


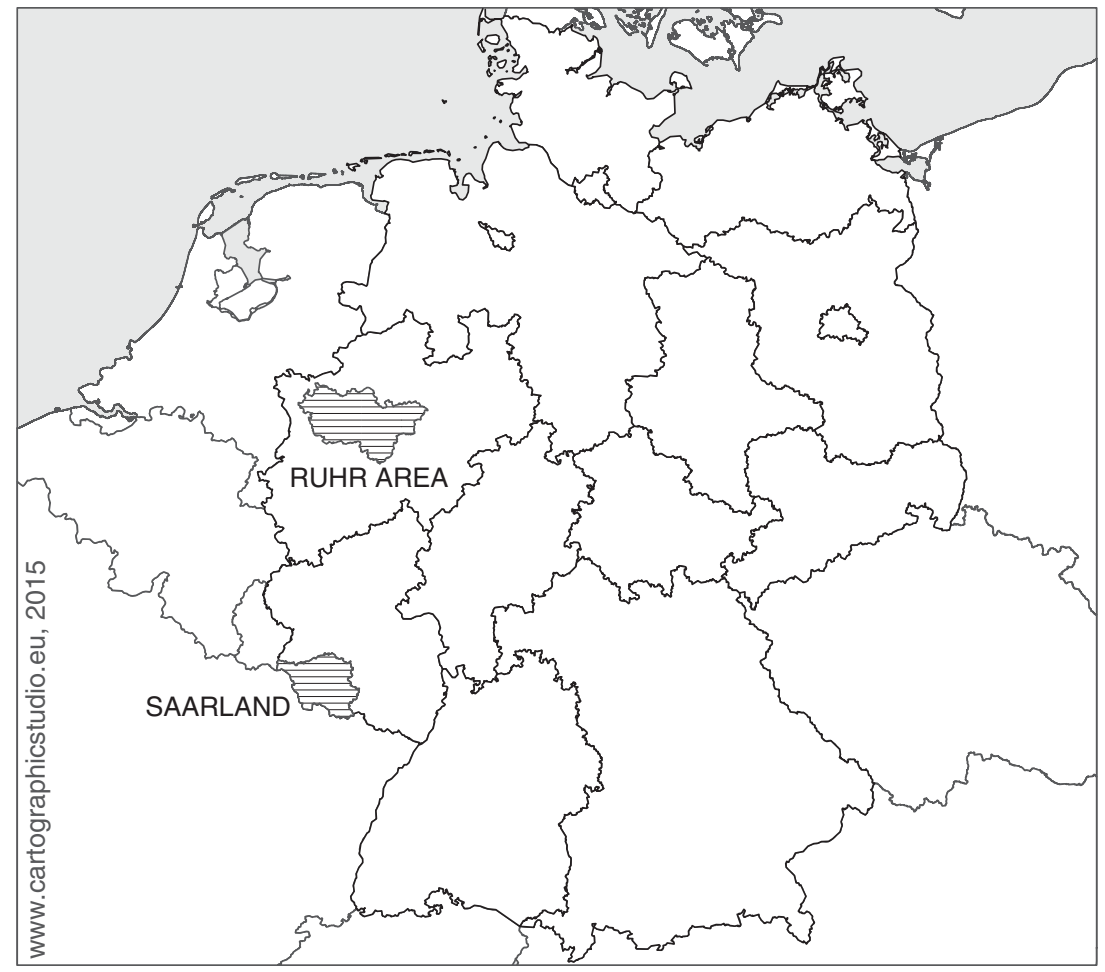

Figure I. Saarland and Ruhr, the two major historical coalmining regions in Germany.

migrants made up a huge part of the miners' workforce. Indeed, immigrants "from the East" comprised over so per cent of the workers in so-called Polish pits before World War I. ${ }^{3}$ After the war football clubs recruited a huge number of players and spectators from among the descendants of the first generation of migrants.

All over the world, there are countless examples of football clubs in mining regions that had a special significance for regional identity, although their mining background is not always reflected in the names. They include Schalke ${ }_{4}$ (Gelsenkirchen) and Borussia Dortmund in the Ruhr, ${ }^{4}$ Club de

3. Christoph Kleßmann, Polnische Bergarbeiter im Rubrgebiet I870-1945: Soziale Integration und nationale Subkultur einer Minderheit in der deutschen Industriegesellschaft (Göttingen, I978), p. 35 . Here it is taken for granted that these were "Poles", even if at that time there was no Polish state.

4. Georg Röwekamp, Der Mythos lebt. Die Geschichte des FC Schalke $0_{4}$ (Göttingen, 1996); Stefan Goch and Norbert Silberbach, Zwischen Blau und Weiß liegt Grau: Der FC Schalke 04 in der Zeit des Nationalsozialismus (Essen, 2005); Gerd Kolbe and Dietrich Schulze-Marmeling, Ein Jabrbundert Borussia Dortmund: 1909 bis 2009 (Göttingen, 2009). For the Ruhr in general, see Siegfried Gehrmann, Fußball - Vereine - Politik: Zur Sportgeschichte des Reviers 1900-1940 (Essen, I988). 
Fútbol Pachuca in Mexico (founded as Pachuca Athletic Club by immigrant British miners and engineers in I 895), Shakhtar (the word means coalminer) Donetsk in Ukraine, ' Górnik (literally, miner) Zabrze in Silesia, the gueules noires (black gobs) of Racing Club de Lens in northern France, ${ }^{6}$ and Roda Kerkrade in the Netherlands. There were also a large number of amateur clubs of coalminers, from Pennsylvania to Kömürspor in northern Turkey. ${ }^{7}$ Significantly Kömürspor is the Turkish word for "coal sport". 8

In many cases miners working in the pits played a major role in organizing the clubs and giving them their identity. Stories about these origins live on as legends and myths in the collective memory of local inhabitants. Political discourse regularly invokes these histories, often in a populist manner, as a reference to the integrative power of sport. Such references are based on the idea that sport is able to overcome problems of ethnic heterogeneity, and to "integrate" immigrants into local society. Using history for their own particular ends, in the last few decades the standard repertoire of politicians of different colours has thus included statements on the positive historical experience of migrants in sports. ${ }^{9}$ For the general public these statements constitute an effet de réel, in the sense of Roland Barthes, insofar as they give the impression that they are describing a social reality in the history of migration. William Gasparini, to whom I owe the reference to Barthes, has revealed similar mythmaking tendencies in France. ${ }^{{ }^{\circ}}$ This article aims to deconstruct this myth in the case of Polish migrants in the Ruhr, by reconstructing the specific conditions of migration, from the starting point in the eastern provinces of the German Reich to the socioeconomic and political backgrounds of their local actions in the Ruhr.

5. See the multi-award-winning documentary on the club's situation before the war in eastern Ukraine, caught between the decline of the mining industry and oligarchic policies: "The Other Chelsea - A Story from Donetsk", a documentary film by Jakob Preuss (2010), available at http://theotherchelsea.com/press.php; last accessed is July 2015 .

6. Marion Fontaine, Le Racing Club de Lens et les "Gueules Noires": Essai d'histoire sociale (Paris, 2010). See also Marion Fontaine's contribution to the present volume.

7. Nicholas P. Ciotola, "Soccer in Coal Country", Western Pennsylvania History, 87:4 (2004), pp. 40-4I, available at https://journals.psu.edu/wph/article/view/5264/5047; last accessed Is July 2015 .

8. Today the club is called Zonguldakspor, after the town of Zonguldak in the northern mining area of Turkey. See Tanil Bora, "Fußballkultur im Ruhrgebiet und am westlichen schwarzen Meer im Vergleich" (unpublished paper, p. 4). Published in part in Der tödliche Pass, 7I (20I4), pp. $58-59$.

9. For example Helmut Schmidt as Chancellor of West Germany, Wolfgang Schäuble as Minister of the Interior, and Johannes Rau as Prime Minister of North Rhine-Westphalia. See Diethelm Blecking, "Sport and Immigration in Germany", The International Journal of the History of Sport, 25 (2008), pp. 955-973, 956 and 967, n. Io.

ı. William Gasparini, "Sport et intégration des immigrés en France. Contribution à une sociologie critique des catégories de pensée" (unpublished paper, Faculté des Sciences du Sport, Université de Strasbourg). 


\section{POLISH MIGRATION AND COMMUNITY BUILDING}

Thou shalt have no other fatherland than an undivided Poland. ${ }^{\text {I }}$

Germany has been a land of immigration since the turn of the twentieth century. In the nineteenth century emigration had always exceeded immigration, until migrants began to arrive from countries such as Austria-Hungary, Italy, and Russia, and from the eastern provinces of Germany itself. Before World War I, internal migration, especially from the Polish areas of the German Reich, ${ }^{\mathrm{I} 2}$ created Polish-speaking minorities, mainly in the Ruhr, Berlin, and some cities in northern Germany. ${ }^{13}$ The migration from the agrarian provinces in the east to the industrial region of the Ruhr was caused by differences in the speed and dynamics of capitalist modernization processes in various parts of the German Reich, resulting in economic underdevelopment and overpopulation in the agrarian areas of the east, the so-called Hinterland of the Reich.

Poles began arriving in the Ruhr in the early i 870 . During the economic boom between I895 and the outbreak of World War I, successive waves of immigration reached a peak as a result of the growing demand for mineworkers. Polish-speaking people poured westwards from Upper Silesia, west Prussia, the area around Poznan, from Masuria, and the southern areas of eastern Prussia. By I9I4, over I30,000 miners from the eastern provinces were working in the collieries in the Ruhr. ${ }^{14}$ Chain migration and Polish migration networks soon destined "Westphalia" to become an "ethnoscape"

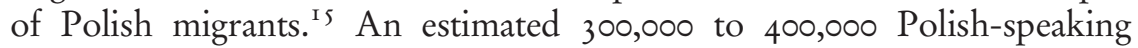
inhabitants were living in the Rhineland-Westphalian industrial region before World War I. ${ }^{16}$ This number excludes the so-called Masurians, who were

I I. From the "Ten Commandments" of Sokół athletes, quoted after Diethelm Blecking, PolenTürken-Sozialisten: Sport und soziale Bewegungen in Deutschland (Münster, 200I), p. 46. All translations from German and Polish are mine.

I 2. For Prussia's and later Germany's policies towards the Polish areas, see Martin Broszat, Zweibundert Jabre deutsche Polenpolitik (Frankfurt am Main, 1972).

I 3. Kleßmann, Polnische Bergarbeiter, pp. 23-43; Anna Poniatowska, Polacy w Berlinie 19I8-1945 [Poles in Berlin I918-1945] (Poznań, 1986); Oliver Steinert, "Berlin - Polnischer Babnhof!" Die Berliner Polen, Eine Untersuchung zum Verhältnis von nationaler Selbstbehauptung und sozialem Integrationsbedürfnis einer fremdsprachigen Minderheit in der Hauptstadt des Deutschen Kaiserreichs (I87I-1918) (Hamburg, 2003); Elke Hauschildt, Polnische Arbeitsmigranten in Wilhelmsburg bei Hamburg während des Kaiserreichs und der Weimarer Republik (Dortmund, 1986); Karl Marten Barfuss, "Gastarbeiter" in Nordwestdentschland I884-I9I8 (Bremen, 1986).

14. Kleßmann, Polnische Bergarbeiter, pp. 37-43, 267.

I 5 . On identities constructed in the process of migration see Dirk Hoerder, Migrations and Belongings: $1870-1945$ (Cambridge [etc.], 2014), p. 67.

I6. Estimates range from up to 350,000 by Kleßmann, Polnische Bergarbeiter, p. 22, to 400,000 by Brian McCook, "Polnische industrielle Arbeitswanderer im Ruhrgebiet ('Ruhrpolen') seit dem Ende des I9. Jahrhunderts", in Klaus J. Bade et al. (eds), Enzyklopädie Migration in Europa: Vom 17. Jahrhundert bis zur Gegenwart (Munich [etc.], 2008), pp. 870-879, 87I. 
often confused with Poles. They were an amalgamation of the local Polish population with other groups, particularly Germans, Huguenots, Scots, and religious exiles from Salzburg (Austria). The Masurians mainly inhabited the east Prussian districts of Ortelsburg, Neidenburg, and Allenstein, and spoke an ancient Polish peasant dialect, were evangelical, and traditionally friendly towards Prussia. ${ }^{17}$

In this same period, the eastern parts of the Reich were the scene of bitter nationality struggles. The Prussian-German administration pursued a rigorous policy of Germanization in an anti-Polish Kulturkampf by repressing the Polish language, replacing Polish priests as school inspectors by Prussian civil servants, expelling Galician and Russian Poles from the province of Poznań and from Upper Silesia, and buying out Polish landowners. ${ }^{18}$ In the end, all these attempts proved to be in vain, however. The result of anti-Polish policies was not to weaken but to strengthen the tender shoots of Polish civil society, developing under social and political pressures "from a loose conglomerate of people with an underdeveloped passive ethnic-national consciousness to a highly organized community with a broad civil, political, and cultural consciousness". ${ }^{19}$

The social life of the Catholic Poles, both in the Polish territories themselves and in the regions they migrated to, was organized in clubs and societies from an early date, first under the patronage of the Catholic Church. But in the process of nationalization and ethnicization other

17. Andreas Kossert, Masuren: Ostpreußens vergessener Süden (Berlin, 200I). Masurian immigration centred on Gelsenkirchen. See Andreas Kossert, "Kuzorra, Szepan und Kalwitzki: Polnischsprachige Masuren im Ruhrgebiet”, in Dittmar Dahlmann, Albert S. Kotowski, and Zbigniew Karpus (eds), Schimanski, Kuzorra und andere: Polnische Einwanderer im Rubrgebiet zwischen der Reichsgründung und dem Zweiten Weltkrieg (Essen, 2005), pp. 169-181. On the active policies of the Prussian administration to win over Masurians for its policy of Germanization, see Brian McCook, The Borders of Integration: Polish Migrants in Germany and the United States, 1870-I924 (Athens, OH, 2012), pp. I 24-I 25.

I8. Bismarck feared a Catholic Polish-Austrian alliance. See Georg Franz, Kulturkampf, Staat und katholische Kirche in Mitteleuropa von der Säkularisation bis zum Abschluß des preußischen Kulturkampfes (Munich, 1954), pp. 214-215. On Germanization policies see also William W. Hagen, Germans, Poles, and Jews: The Nationality Conflict in the Prussian East 1772-19I4 (Chicago, IL [etc.], I980); Helmut Glück, Die preußisch-polnische Sprachenpolitik: Eine Studie über Theorie und Methodologie der Forschung über Sprachenpolitik, Sprachenbewußtsein und Sozialgeschichte am Beispiel der preußisch-deutschen Politik gegenüber der polnischen Minderheit vor 1914 (Hamburg, 1979); Mark Tilse, Transnationalism in the Prussian East: From National Conflict to Synthesis, I87I-I9I4 (Basingstoke [etc.], 20I I); Lech Trzeciakowski, Kulturkampf w zaborze pruskim [Kulturkampf in the Prussian Part of Partitioned Poland] (Poznań, I970); Richard Blanke, "Bismarck and the Prussian Polish Policies of I 886", Journal of Modern History, 45 (1973), pp. 2 I I-239; Helmut Neubach, Die Ausweisungen von Polen und Juden aus Preussen I885/86: Ein Beitrag zu Bismarcks Polenpolitik und zur Geschichte des deutsch-polnischen Verbältnisses (Wiesbaden, 1967).

19. Witold Jakóbczyk, Studia nad dziejami Wielkopolski [Studies in the History of Greater Poland], III (Poznań, I967), p. 4. 


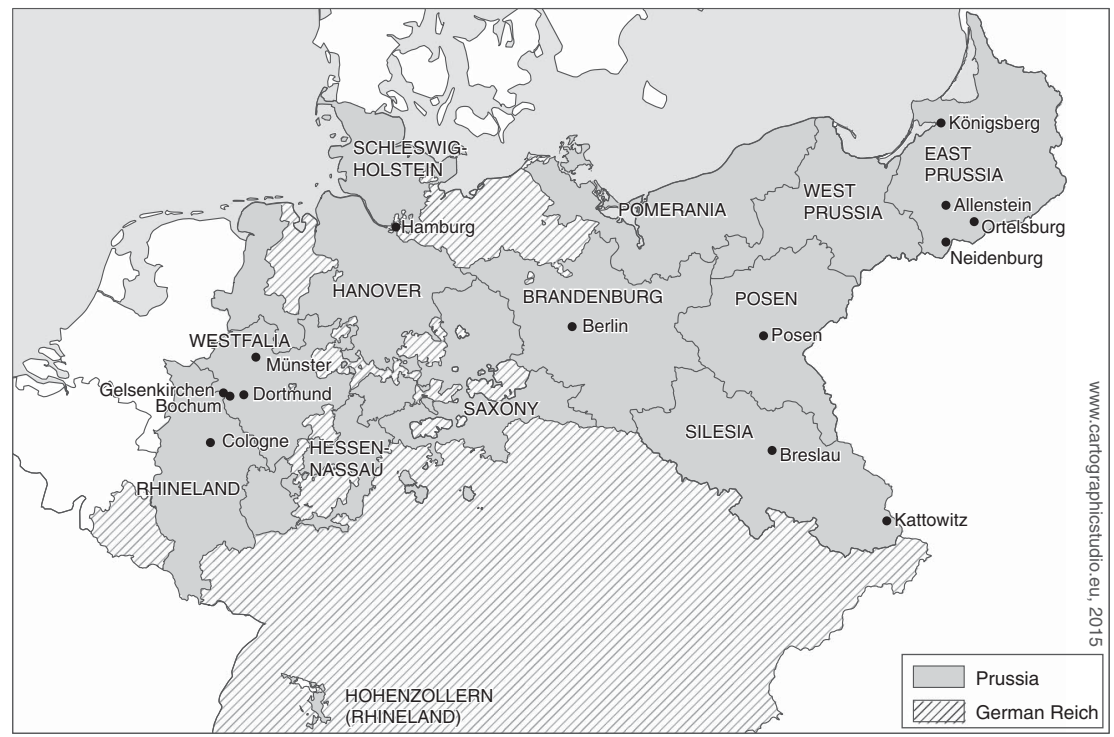

Figure 2. The German Reich, Prussia, and Prussia's western and eastern provinces before World War I.

organizations were founded that were more independent of the church (see Table I, p. 9). The proliferation of institutions arising from this process may be characterized by the modern term "community building". ${ }^{20}$ This phenomenon had already been described in contemporary literature on Polish migration. In 1907 Ludwig Bernhard wrote about das polnische Gemeinwesen (Polish community life), ${ }^{21}$ and on the Polish side the term społeczeństwo (community) was used to designate Polish organizational structures within the Prussian state. ${ }^{22}$

Increasing ethnic tensions soon became apparent in the colonies of immigrants in the German Reich. Political and cultural repression by the Prussian-German administration led to a process of politicization among Poles, resulting in the creation of intra-ethnic networks stretching from the eastern provinces via Berlin to the Ruhr. ${ }^{23}$ Strictly speaking, under the

20. The use of the contemporary notion of "community building" in Germany dates back to the I 980 s and the debates at the time about Turkish migration. See, for instance, Jürgen Fijalkowski, "Ethnische Heterogenität und soziale Absonderung in deutschen Städten. Zu Wissensstand und Forschungsbedarf", Occasional Papers No. I 3 of the research cluster "Ethnizität und Gesellschaft" at the Free University Berlin (Berlin, I988).

21. Ludwig Bernhard, Das polnische Gemeinwesen im preußischen Staat (Leipzig, 1907).

22. Diethelm Blecking, Die Geschichte der nationalpolnischen Turnorganisation "Sokót" im Deutschen Reich I884-1939 (Münster, 1987), p. 2 16.

23. For an overview of recent literature on Polish migration in Germany, see Aleksander Żerelik, "Polen in Deutschland. Eine Bibliographie (1989-20II)", in Basil Kerski and Krzysztof 


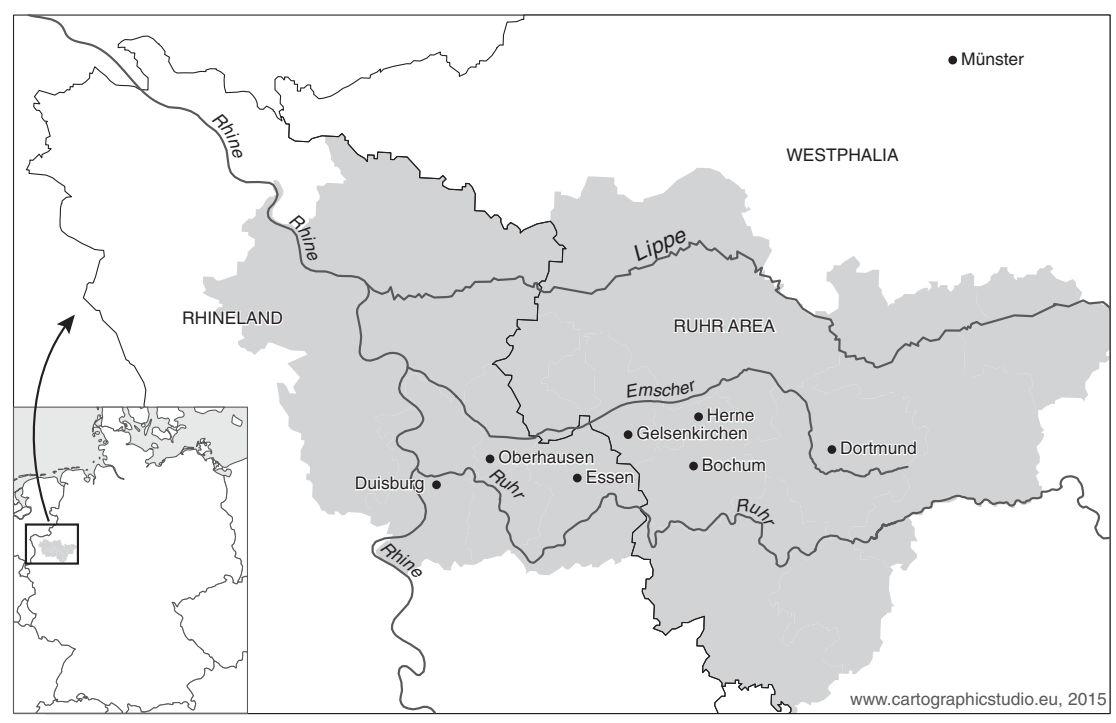

Figure 3. The Ruhr industrial region.

constitution of the German Reich, Polish migration was internal migration until the foundation of the Second Polish Republic in I9r 8. The majority of Polish migrants held Prussian citizenship; a more overall German citizenship only existed after $1913{ }^{24}$

Polish sporting organizations took over the watchwords of national democracy and saw themselves as a part, indeed a material surrogate, of the construction of an imaginary Polish state, connecting areas of origin and migrant communities in the west. Starting in I884 as a reaction to the pressures of Germanization, people in and around Poznań began to set up Polish sports clubs to strengthen their social framework. Most of these were gymnastic clubs that went under the name of Sokół ("Falcon"). They were part of a movement in small towns of mostly craftsmen and small-scale entrepreneurs, who participated in the fragile and fledgling process of the modernization of Polish society. The activities of these clubs were modelled

Ruchniewicz (eds), Polnische Einwanderung: Zur Geschichte und Gegenwart der Polen in Deutschland (Osnabrück, 20I I), pp. 299-316. See also Sylvia Haida, Die Ruhrpolen: Nationale und konfessionelle Identität im Berwusstsein und im Alltag I87I-I9I8 (Bonn, 20I2); Valentina Maria Stefanski, Zum Prozess der Emanzipation und Integration von Außenseitern: Polnische Arbeitsmigranten im Rubrgebiet (Dortmund, 1984); Jacek Barski and Dietmar Osses (eds), Polen in Deutschland: Geschichte und Kultur (Essen, 2013); Peter Oliver Loew, Wir Unsichtbaren: Geschichte der Polen in Deutschland (Munich, 2014).

24. For the I91 3 definition of German citizenship, see Reichs- und Staatsangebörigkeitsgesetz vom 22. Juli 1913 (Reichs-Gesetzblatt 1913, pp. 583-593), available at http://www.documentarchiv.de/ksr/ I9I $3 /$ reichs-staatsangehoerigkeitsgesetz.html; last accessed is July 20 I 5. 
on those of the German Turnvereine (gymnastic clubs). Polish-speaking citizens had been denied membership of the German clubs in and around Poznań. In I 893, the headquarters of the first umbrella organization of the Sokół, called the Związek Sokołów Wielkopolskich [Greater Polish Sokół League], were set up there. ${ }^{25}$

From I 899 onwards Polish Sokół clubs began to be set up in the Ruhr as well, the first in Oberhausen. ${ }^{26}$ As in the area around Poznań, Polish migrants in the Ruhr diaspora had become more aware of their identity in conflicts with the authorities, for instance during a spontaneous strike by Polish coalminers in Herne in 1899 , the so-called Krawalle von Herne ("Herne revolts"), when the army was used to put down the strikers. On the Polish side two people died and another thirty were injured. ${ }^{27}$ The striking Polish miners were not only isolated from their Masurian workmates, but also from the German miners refusing to support them. German xenophobia rather than the supposed "rural attitudes" of the Poles stood in the way of working-class solidarity. ${ }^{28}$ Poles working in the collieries had once emigrated from the agricultural east and lost their traditional way of living, a process that can be described as social uprooting resulting in a situation of deprived rights. ${ }^{29}$ All this explains a yearning for a stable Polish framework, not only in their leisure activities, but also in a separate trade union, the Zjednoczenie Zawodowe Polskie [Polish Trade Union]. ${ }^{30}$

Table I shows that in I9I 2 the total membership of the Sokó clubs in the Ruhr was only around 7,000; nonetheless, they were the second largest

25. For an overview of the early history of Polish sports clubs, see Blecking, Die Geschichte der nationalpolnischen Turnorganisation, pp. 70-75.

26. Anna Ryfowa, Dziatalność Sokoła Polskiego w zaborze pruskim i wśród wychodźstwa w Niemczech, I888-I9I4 [The Activities of the Polish Sokół in the Prussian Part of Partitioned Poland and Among Emigrants in Germany, I888-1914] (Warsaw [etc.], 1976), and Blecking, Geschichte der nationalpolnischen Turnorganisation. See also Marek Szczerbiński, Zarys dziatalności Sokolstwo Polskiego na obczyźnie w latach I887-1918 [Overview of the Activities of the Polish Sokół Abroad, I887-I918] (Katowice, I982), and idem, "Sokolstwo Polskie w Niemczech w latach I889-19r8" [The Sokół in Germany during the Years I 889-1918], Wychowanie fizyczne i sport [Physical Education and Sport], I (1976), pp. 85-107.

27. Klaus Tenfelde, “Die 'Krawalle von Herne' im Jahre i 899”, Internationale Wissenschaftliche Korrespondenz zur Geschichte der deutschen Arbeiterbewegung, I (1979), pp. 7 I-104.

28. For a fundamental study offering a revision of the view that the "backwardness" of Polish miners in the Ruhr acted as an obstacle to militancy and solidarity, including a detailed analysis of the I 899 strike, see John J. Kulczycki, The Foreign Worker and the German Labour Movement: Xenophobia and Solidarity in the Coal Fields of the Ruhr, I87I-I9I4 (Oxford [etc.], 1994).

29. On the process of deracination, acculturation, and assimilation in the context of the confrontation between large groups and minorities, see Hoerder, Migrations and Belongings, pp. 56-59.

30. For a detailed history of the Zjednoczenie Zawodowe Polskie see John Kulczycki, The Polish Coal Miners' Union and the German Labor Movement in the Ruhr, 1902-1934: National and Social Solidarity (Oxford [etc.], 1997). On the panoply of Polish leisure activities in the Ruhr before 1918, see Haida, Rubrpolen, pp. 293-306. 
Table I. Number of organizations and their membership in the Polish community in the Rubr (I9I2)

\begin{tabular}{lrc}
\hline TYPE OF CLUB OR ASSOCIATION & NUMBER & MEMBERS \\
\hline Church working men's clubs & 244 & 30,929 \\
Rosary fraternities & 68 & 16,297 \\
Voter associations* & 100 & 8,412 \\
Sokół clubs & 117 & 6,909 \\
Choral societies & 95 & 5,225 \\
Education associations (Oswiata) & 16 & 3,488 \\
Straz (= guard) associations ${ }^{*}$ & 17 & 1,750 \\
Lottery clubs & 70 & 1,563 \\
Youth clubs & 19 & 1,345 \\
Cooperatives, consumer associations & 4 & 890 \\
Theatre and music clubs & 37 & 889 \\
Trade associations & 16 & 724 \\
Abstinence clubs & 25 & 695 \\
Women's clubs & 9 & 474 \\
Local Polish socialist groups (PPS) & 9 & 408 \\
Others & 29 & 1,534 \\
\hline
\end{tabular}

*Polish political clubs to organize votes for Polish political interests.

\#Aristocratic, nationalistic, and conservative Polish political clubs with a focus on the eastern provinces.

Source: Kleßmann, Polnische Bergarbeiter, p. I03.

group in the network of Polish organizations. Having said that, the number of Poles organized in Sokól clubs in relation to the number of Polish migrants in the Ruhr ( 1.75 per cent) was higher than the number of German members in German gymnastic clubs ( 1.66 per cent) in relation to the number of Germans in the Reich. ${ }^{3 \text { I }}$ This is all the more remarkable when we consider that the presence of sporting organizations among industrial workers before World War I, and even up to the present day, ${ }^{32}$ was considerably smaller than that among the middle classes. The overwhelming majority of members of the Sokól clubs in the Ruhr were mineworkers, as can be seen from a random sample of nineteen clubs in the district of Münster, administratively responsible for the north of the Ruhr: over 90 per cent of the board members were miners. ${ }^{33}$

31. Figures in Christiane Eisenberg, "Deutschland", in idem (ed.), Fußball, soccer, calcio. Ein englischer Sport auf seinem Weg um die Welt (Munich, 1997), pp. 94-I 29, 97; Hans-Ulrich Wehler, Deutsche Gesellschaftsgeschichte. Bd. 3: Von der "Deutschen Doppelrevolution" bis zum Beginn des Ersten Weltkrieges, I849-I9I4 (Munich, I995), p. 494. See also Christiane Eisenberg, "Massensport in der Weimarer Republik: Ein statistischer Überblick", Archiv für Sozialgeschichte, 33 (1993), pp. I37-177.

32. Simone Becker and Sven Schneider, "Ausmaß und Korrelate sportlicher Betätigung bei bundesdeutschen Erwerbstätigen”, Sport und Gesellschaft, 2 (2005), pp. 173-204.

33. Blecking, Geschichte der nationalpolnischen Turnorganisation, p. I 17. 
Due to a lack of data it is impossible to establish whether a significant number of Poles were members of German gymnastic clubs. This is highly implausible, however, given that Polish migrants were isolated from Prussian-German society, and that the German Turnvereine played a major role in the concept of German national cultural hegemony. As in the area around Poznań, German gymnastic clubs worked hand in hand with German nationalist organizations, such as the Deutscher Ostmarkenverein and the Alldeutscher Verband (All-German League), which campaigned for a hard-line policy of Germanization. ${ }^{34}$

The Sokół clubs' physical exercises were useful not only in creating a sense of personal identity, but also in developing a new social identity and in promoting national ideas among the Polish community in the Ruhr. Even if the exercises were based on the repertoire of German gymnastic clubs, the festive mass open-air exercises organized by Sokół clubs featured Polish red and white flags and Ulan lances. ${ }^{35}$ In this way, the Sokó gymnastic movement presented itself as an embodiment of the Polish nation. This is clearly in contrast to the more widespread idea of "integration through sports" which is, as mentioned earlier, a hallmark of contemporary political discourses. Polish clubs can instead be described as vehicles for preventing this kind of "integration" (understood as "assimilation") of Polish migrants into German society.

If we follow the classical sociological arguments, which consider marital behaviour as a key indicator of assimilation, ${ }^{36}$ the Polish community in the Ruhr was extremely successful in preventing such an assimilation process. Before I9I4 mixed marriages were very rare. ${ }^{37}$ This is a clear indication of mutual ethnic and social segregation. Polish clubs and associations helped people to survive in a fragmented and segmented society. Setting up their own organizations was a logical answer to exclusion. ${ }^{38}$ Both its members and its opponents recognized the highly symbolic value of the Sokół movement for the internal fostering of the Polish spoteczeństwo. Based on an avant-garde elite consciousness, the clubs helped to build Polish organizational structures that offered migrants opportunities to act on their own initiative and to consolidate their new identity. Polish sports clubs were thus rather part of social diversity within a segmented society than a sign of any kind of "melting pot". 39

34. Ibid., pp. I49-159.

35. See Diethelm Blecking, "Sokolfeste der Ruhrpolen", in Hans-Joachim Teichler (ed.), Sportliche Festkultur in geschichtlicher Perspektive (Clausthal-Zellerfeld, I990), pp. 34-48. 36. See, for instance, Milton M. Gordon, Assimilation in American Life: The Role of Race, Religion, and National Origins (New York, 1964), p. 7r.

37. Kleßmann, Polnische Bergarbeiter, p. 28I. Members of the Sokół league were disciplined if they married a German woman; Blecking, Polen-Türken-Sozialisten, pp. 45-46, n. Io9.

38. See also McCook, The Borders of Integration, pp. I44-I45.

39. Richard Murphy resorted to the notion of "melting pot" when writing, in a rather euphemistic way, about the Poles in the Ruhr: "The destiny of these people is a success story of 
In the Wilhelmine era (I888-I9I8) migrant organizations did not have the bridge-building role that has often been attributed to them. The same applies to the supposed "bridging social capital" of sport. ${ }^{4}$ Sport did not offer opportunities for meeting and intermingling, but instead reflected the social, political, and ethnic divisions in Wilhelmine society. In addition to the nationalist German Turnvereine and the Polish Sokól clubs, there were also clubs associated with the socialist workers' gymnastic movement and the Jewish Zionist gymnastic movement. ${ }^{4 \mathrm{I}}$ There were no sports meetings or competitions between these organizations and their members.

Competitive modern sports, often called in the parlance of the time "English sports", mainly football, athletics, and cycling, had arrived in Germany as early as the i 870 . The centres of these sporting movements were in the sophisticated cities of Hamburg and Berlin, but industrial workers remained excluded from such sports. Originally, members of the old middle class and educated layers of society, such as students, doctors, lawyers, and professors had had the upper hand in the gymnastic clubs (until this was challenged by the workers' and ethnic-minority gymnastic movements mentioned above). In the new sports, however, it was members of the new class of white-collar employees, attaching great importance to distinguishing themselves from the working class, who dominated the disciplines of cycling, football, and athletics and comprised the largest group in the corresponding clubs (more than half)..$^{42}$

Modern sport functioned as a social medium for members of the new middle class (including those of Jewish background) who were excluded from the social elite and their caste-like rituals (like those of reserve officers). ${ }^{43}$ At the same time, modern sport clubs also wanted to fulfil a "national mission". ${ }^{44}$ All these characteristics combined meant that in this period football in the Ruhr was not a social or political arena for Polish working-class miners.

American dimensions"; Richard C. Murphy, Gastarbeiter im Deutschen Reich, Polen in Bottrop I89I-I933 (Wuppertal, I982), p. I84.

40. Andrei S. Markovits, Sport: Motor und Impulssystem für Emanzipation und Diskriminierung (Vienna, 20II), p. 40.

4I. For overviews of the socialist and Jewish gymnastic movements in Germany, see Diethelm Blecking (ed.), Arbeitersport in Deutschland 1893-1933: Dokumentation und Analysen (Cologne, 1983); Lorenz Peiffer and Henry Wahlig, Jüdischer Sport und Sport der Juden in Deutschland: Eine kommentierte Bibliografie (Göttingen, 2009).

42. Christiane Eisenberg, "English sports" und deutsche Bürger. Eine Gesellschaftsgeschichte, I800-1939 (Paderborn, I999), p. 2 I I.

43. Wehler, Gesellschaftsgeschichte, pp. 1065-1066.

44. Eisenberg, "English sports", pp. I78-2 I 4. 


\section{AFTER THE GREAT WAR - THE ROAD TO ASSIMILATION}

During World War I internal social and political conflicts in Germany were - for the time being - eased or postponed by the so-called Burgfrieden between the Wilhelmine state and the workers' movement. The Ruhr also witnessed a lessening of the tensions between Poles and Germans, with many Poles loyally enlisting in the German armed forces. In February I9I 7 a submission by a Westphalian section of the Sokó League to the head of the police in Bochum summed up the price paid for this loyalty:

To date $\mathrm{I} 42$ heroes have lost their lives and 9I Polish gymnasts in our district have been awarded the Iron Cross. All of them have fulfilled their military duties with great commitment and loyalty, as shown by the many promotions to the rank of non-commissioned officer. Gymnastic preparations in our clubs have helped them immensely to bear the stresses of war. ${ }^{45}$

After the re-establishment of the Polish state in I9I 8, the situation of the Polish inhabitants in the Ruhr changed dramatically. It is therefore hardly possible to compare the history and situation of Polish migrants in the Ruhr before and after World War I. Until January 1922 fewer than 50,000 of them opted to return to Poland, ${ }^{46}$ and between 50,000 and 80,000 migrated further on to mining regions in Belgium, France, and the Netherlands. In I 929 the Polish consulate in Essen estimated that there were only around I 50,000 Poles still living in the Ruhr. ${ }^{47}$ This meant that the social basis of the clubs and associations had been reduced considerably. By 1924 the Sokó League in the Ruhr had only I,227 members, of whom a mere 460 were active. ${ }^{48}$ The steep decline in membership led to its dissolution in 1927 and its replacement by the Verband der Turn- und Sportvereine in Westfalen und im Rheinlande [League of Gymnastics and Sports Clubs in Westphalia and the Rhineland]. The League formulated a new aim for the sporting movement of the Polish minority: "[T] hat the Polish minority and German citizens who speak the Polish language should once and for all be allowed to take part in official German competitions and compete for victory with German representatives." 49

Football had made its appearance in the Sokó movement at the end of World War I and had established itself as early as 1920. Despite the continuing resistance of traditionalists among its members, footballers increasingly expressed a wish to be able to compete against German football teams. In May 1927 the first proud reports of such competitions

45. Landesarchiv Nordrhein-Westfalen Abteilung Westfalen, Münster, Regierung Münster, Abteilung VII 34p, Bd. I.

46. Kleßmann, Polnische Bergarbeiter, p. I 2.

47. Ibid., pp. 165-166.

48. Blecking, Geschichte der nationalpolnischen Turnorganisation, p. I96.

49. Gesamtüberblick über die polnische Presse (1927), p. 197. 
were published. ${ }^{\circ}$ Contrary to the situation before World War I, for those Poles who had chosen to stay there was no real alternative to engaging with German society and therefore to joining shared competitions. For a footballer a career in a "Polack and proletarian club" 5 now became an "active opportunity for assimilation". 52 This change in the aims and strategies of the Polish sporting movement in the Ruhr reflected the end of the self-referential community of Polish migrants. ${ }^{53}$

During World War I football had spread widely among soldiers due to its importance as a military sport. ${ }^{54}$ After the troops were demobilized it retained its popularity as an extremely hard competitive sport, which seemed to match the experiences at the front. It is noteworthy that the first game played by Schalke ${ }_{4}$ after the war was a match against the paramilitary Freikorps Hacketau. Other infamous paramilitary clubs like the Freikorps Pfeffer, Lützow, and the Marinebrigade Ehrhardt also played against "civilian" clubs. Attendance figures at the final games in the German league championship rose to over 50,000, and the league game between Hamburg and the Berlin club Union Oberschöneweide in 1923 attracted a crowd of 64,000 . Whereas the number of members in the Deutscher Fußball Bund [German Football Association, DFB] was 161,600 in 1913 , by I92 I this figure had grown fivefold to almost $780,500 .{ }^{55}$ But here, too, white-collar workers and members of middle-class professions continued to predominate. ${ }^{56}$

In the Ruhr the situation looked completely different. There, football had a decidedly multi-ethnic and proletarian dimension, turning it into an ever more popular sport among the immigrant population. ${ }^{57}$ In the vicinity

50. See the following report from a Polish-language monthly published in Germany: Polak w Niemczech [The Pole in Germany], no. 5: I, May 1927.

51. This was what FC Schalke 04 was called in the I 920 s because of the many players from the coalmining community with Polish-sounding names; Siegfried Gehrmann, "Der F.C. Schalke 4$_{4}$ ", in Wilhelm Hopf (ed.), Fußball: Soziologie und Sozialgeschichte einer populären Sportart (Weinheim, 1979), pp. I I7-I 3 I.

52. Hartmut Esser, Aspekte der Wanderungssoziologie: Assimilation und Integration von Wanderern, ethnischen Gruppen und Minderheiten (Darmstadt [etc.], I980), p. 2 I I.

53. But even in the years of the Weimar Republic many migrants kept up social contacts almost exclusively with other people of Polish descent; Ralf Karl Oenning, "Du da mitti polnischen Farben ...": Sozialisationserfahrungen von Polen im Ruhrgebiet 19I 8-1939 (Münster [etc.], I991), p. I 29 .

54. Peter Tauber, Vom Schützengraben auf den grünen Rasen: Der Erste Weltkrieg und die Entwicklung des Sports in Deutschland (Berlin, 2008), pp. 239-258.

55. Eisenberg, "Deutschland", pp. I04-106.

56. Idem, "Massensport", p. I67.

57. On how this multi-ethnicity was reflected upon in the contemporary German and Polish press, see Britta Lenz, “'Gebürtige Polen’ und 'deutsche Jungen’: Polnischsprachige Zuwanderer im Ruhrgebietsfußball im Spiegel von deutscher und polnischer Presse der Zwischenkriegszeit”, in Diethelm Blecking, Lorenz Pfeiffer, and Robert Traba (eds), Vom Konflikt zur Konkurrenz: Deutsch-polnisch-ukrainische Fußballgeschichte (Göttingen, 20I4), pp. I00-I I 3. 
of large collieries teams were set up consisting mainly of working-class members. Indeed, there were now many players with Polish names in Ruhr teams, ${ }^{58}$ for example in the long-established Rot-Weiss Essen. From I919 onwards a huge number of new members with Polish-sounding names joined the club, where they also worked as officials and employees. By 1939 they made up around Io per cent of the membership. In I93 I the club took on a groundsman by the name of Hermann Greszick, who changed his name to Kress in I932. A change of name can generally be seen as a clear sign of assimilation, and there was a definite thrust towards this in the I930s. Other players changed their names from Regelski to Reckmann, from Czerwinski to Rothardt, or from Zembrzyki to Zeidler. Around 240,000 people of Polish and Masurian origin in the Ruhr are estimated to have "Germanized" their names by 1937. ${ }^{59}$ Polish names could also now be found in socialist workers' sports clubs in the Ruhr, as in the board of the Essen Arbeiter-Turn- und Sportverein Schonnebeck. Hence, it can be assumed that during the Weimar Republic people of Polish origin were not only members of Polish sporting associations but also of other sports clubs, all the way down to the small socialist workers' clubs.

Becoming an active footballer in a well-known club was one of the opportunities open to younger members of migrant families to improve their social status. Players with a Polish immigrant background were now particularly active in higher-league football in the Ruhr. Of the fifteen clubs that competed in the district championships in the Westphalia and Lower Rhine leagues in the 1937/1938 season, all without exception fielded players with Polish family names such as Rodzinski, Pawlowski, Zielinski, Sobczak, Lukasiewicz, Tomaszik, or Piontek in at least one of the matches. ${ }^{60}$ Of all the players selected for a championship match (around 250), 68 had Polish family names. In addition, the German national team at the time featured players with names like Szepan, Kuzorra, Gellesch, Urban, Kobierski, Zielinski, and Rodzinski.

The first four players in this list were all members of FC Schalke 04 of Gelsenkirchen. The history of this very prototype of a "Polack and proletarian club", however, makes clear how ambivalent relations in the immigrant society of the Ruhr had become. Between 1934 and 1942 Schalke was German league champion on no less than six occasions. The team was full of players with Polish-sounding names, the best known of whom were the

58. An assessment of the multi-ethnic quality of football after World War I is complicated, however, because it is impossible to differentiate between "Poles" and "Masurians" on the basis of their names alone.

59. Werner Burghardt, "Namensänderungen slawischer Familiennamen im Ruhrgebiet", in Günter Bellmann, Günter Eifler, and Wolfgang Kleider (eds), Festschrift für Karl Bischoff zum 70. Geburtstag (Cologne [etc.], I975), pp. 27I-286.

60. Lenz, “'Gebürtige Polen”, p. Iо5. 
stars who also played for the German national team, Ernst Kuzorra and Fritz Szepan. When Schalke won the championship for the first time in 1934, and the team posed for the camera with the Hitler salute, the Polish press spoke scornfully of "Poles [as] German Champions", whereupon the club management hastened to ascertain that "all our players' parents were born in present-day or former Germany and they are not Polish emigrants". ${ }^{6 r}$

In any case, the claims made in the German and Polish press were constantly at odds with the tangled realities. The majority of the parents of the Schalke players came from the southern part of eastern Prussia, and as Protestant Masurians, who had remained faithful to Prussia, did not consider themselves to be "Polish". Indeed, thirty Schalke 04 players between I 920 and I 940 can be identified as Masurians, and another three were born in Masuria. ${ }^{62}$ In this way, the Schalke 04 championship team mirrored the complicated migration history of the Ruhr. During the Third Reich, it was players from Polish and Masurian families who ensured the strength of football in the Ruhr, in particular of Schalke ${ }^{4}$, but also of the German national team. National-Socialist so-called Volkstumsforschung, i.e. pseudo-scientific studies of Germanhood based on anti-Polish, racist, and biologistic principles, managed to solve this dilemma by restricting their studies in the Ruhr to Masurians, who were declared to be "purely German in their culture and way of thinking". As to the Poles in the Ruhr, it also saw indications of what it designated successful Umvolkung through the Germanization of "inferior" foreign migrants. ${ }^{63}$

Schalke 04 was correspondingly instrumentalized to serve unconditionally the propaganda of the regime. The deputy chair of the club, a Jewish dentist, had been forced to resign as early as I933, following pressure from the National Socialists. Kuzorra and Szepan allowed themselves to be drawn into the Nazi propaganda machine, be it more out of opportunism than of conviction. The latter even profited from the Nazis' so-called Aryanization policies, when he took over the Jewish Julius Rhode department store in Schalke's market square.

By contrast, the remainder of Polish sport was mercilessly persecuted, despite Hitler's tactical speech to the Reichstag on I7 May I933, when he spoke out against Germanization. ${ }^{64}$ In January 1934 the Polish newspaper Naród summed up the situation during 1933 as follows:

It was a year in which Polish sporting life in Germany came to a complete standstill. We are forced to declare that the national revolution was the reason

6I. Quoted by Britta Lenz, “'Polen deutsche Fußballmeister”? - Polnischsprachige Einwanderer im Ruhrgebietsfußball der Zwischenkriegszeit”, in Dahlmann et al., Schimanski, Kuzorra und andere: Polnische Einwanderer, pp. 237-250, 248.

62. Ibid., p. 245 .

63. Lenz, "'Gebürtige Polen'”, p. i Iо.

64. Blecking, Die Geschichte der nationalpolnischen Turnorganisation, p. 203, n. 3 . 
behind this fact. We must openly state that it is uncertain that it will ever be able to recover. In the pursuit of opponents to the current regime our sporting sections have been dissolved and their playing fields and exercise rooms withdrawn. As a result this has led to a complete destruction of Polish sporting activities. ${ }^{65}$

Polish sport in the Ruhr never recovered, in spite of the astonishing fact that the five international matches between Germany and Poland between I 933 and 1938 attracted a huge number of spectators and took place in an apparently friendly and sporting atmosphere. ${ }^{66}$ In September 1939, just a few days before the German invasion of Poland, all organizations belonging to the Polish minority in Germany were banned, and their assets confiscated. ${ }^{67}$ By this time 249 members of the Polish minority had been interned in concentration camps. ${ }^{68}$ In this way, after two generations, the history of Polish sport in the Ruhr came to a close.

\section{THE POSTWAR PERIOD: THE THIRD GENERATION}

The years of Nazi barbarity had a watershed effect on the collective memories of German citizens. In relation to football, memories of Jewish and Polish-born players in the German team and at club level were either wiped out, or turned into idyllic folklore tales. ${ }^{69}$ The history of Polish clubs was completely repressed, even though the past continued to live on in family names and careers.

A player like Hans Tilkowski, for example, who played for Germany in the I960s and made a legendary name for himself as the "man in the Wembley goal" in 1966, was the son of a collier from Dortmund, grew up on a coalmining housing estate, and began his career as a goalkeeper for Westphalia Herne. His time at Borussia Dortmund marked the high point of his career, alongside his participation in the final of the World Cup in England in 1966, where the German team were the runners-up. But the true

65. Gesamtüberblick über die polnische Presse (1934), p. 25 , translation from Naród [Die Nation], 6 January i 934 .

66. Dieter Hertz-Eichenrode, "Sportsfreunde? Die deutsch-polnischen Fußball-Länderspiele von 1933-1938", in Blecking et al., Vom Konflikt zur Konkurrenz, pp. I I4-I 22.

67. Verordnung über die Organisationen der polnischen Volksgruppe im Deutschen Reich, 27. Februar 1940 (Reichsgesetzblatt, Teil I 1940, p. 444), available at http://de.wikisource.org/wiki/ Verordnung_\%C3\%BCber_die_Organisationen_der_polnischen_Volksgruppe_im_Deutschen_ Reich; last accessed is July 2015.

68. Valentina Maria Stefanski, "Die polnische Minderheit zwischen I91 8 und 1939/45", in Dagmar Kift and Dietmar Ossens (eds), Polen-Rubr: Zuwanderung zwischen I87I und heute (Essen, 2007), pp. 33-43.

69. The idea of "having no history" dominated the discussion on migration in Germany until well into the I990s. See Ulrich Herbert, Arbeit, Volkstum, Weltanschaunng: Über Fremde und Deutsche im 20. Jahrbundert (Frankfurt am Main, I995), p. 2 I 8. The following considerations about postwar development refer to West Germany only. The development of football in the GDR and its interrelations with collective memories would need a separate analysis. 
star of football from the Ruhr was Reinhard "Stan" Libuda (I943-I996), who died a tragic early death at the age of fifty-three. Libuda played for Schalke, Dortmund, and the German national team, and was vaguely aware of the similarity between his career and background and that of the legendary French footballer Raymond Kopa(szewski), who was born in I93 I in the mining area of Nord-Pas-de-Calais. ${ }^{70}$ Although at that time this theme was generally ignored, a huge number of other players in Germany had names that rang with the history of Masurian and Polish migration. $^{71}$

The long overdue introduction of professional football into Germany between 1963 and 1970 changed its setup profoundly, making it much more open for careers from below. ${ }^{72}$ Anyone with enough talent could now participate, and at the start of the I970s the proportion of working-class players in the top German leagues was, for the first time, equal to their proportion in the population as a whole. At the same time, the German market became attractive to foreign professionals, including Polish players. The first Pole to play for a German club was Waldemar Piotr Słomiany, who moved from Górnik Zabrze in the mining area of Upper Silesia - a club whose mining origins are proudly proclaimed in its name - to Gelsenkirchen to play for Schalke 0 . $^{73}$

Today, there are around 2 million Polish-speaking people living in the Federal Republic of Germany, approximately 2.5 per cent of the population. Since the r 980 s the Ruhr has again become the centre of new waves of Polish migrants, who have built up fresh networks of clubs. ${ }^{74}$ These include the League of Polish Sports Clubs set up in 2005, whose football teams take part in German leagues. ${ }^{75}$ Players from immigrant surroundings, like Klose and Podolski, who were both born in Poland, were pillars of the German national team for many years. And history seemed to be repeating itself when the national

70. Thilo Thielke, An Gott kommt keiner vorbei. Das Leben des Reinhard "Stan" Libuda (Göttingen, 2002); Raymond Kopa, Pitka i ja [The Ball and Me] (Warsaw, 1975); and idem, Kopa (Paris, 2006). See also the article by Marion Fontaine in the present volume.

7r. See the alphabetical list of German international players from Abramczyk to Zwolanowski in Dietrich Schulze-Marmeling, Die Geschichte der Fußball-Nationalmannschaft (Göttingen, 2008), pp. $657-664$.

72. See Eisenberg, "Deutschland", pp. ins-ir6; Nils Havemann, Samstags um halb 4. Die Geschichte der Fußballbundesliga (Munich, 2013), pp. 53-68.

73. Ulrich Homann, "Die ausländischen Spieler beim FC Schalke 04 ", in Holger Jenrich (ed.), Radi, Buffy und ein Sputnik. Ausländer in der Fußball-Bundesliga 1963-1995 (Essen, 1996), pp. 86-88.

74. Christoph Pallaske, "Langfristige Zuwanderungen aus Polen in die Bundesrepublik Deutschland in den r980er Jahren", in Kerski and Ruchniewicz, Polnische Einwanderung, pp. $215-225$.

75. Veronika Grabe and Andrzej Kaluza, "Polnischsprachige im Revier - die Ruhrpolen von heute?", in Kift and Ossens, Polen-Ruhr, pp. 64-73. 
conservative Polish newspaper Rzeczpospolita described the victory of the German team at the World Cup in Brazil as "an extra satisfaction for us" (meaning Poland), ${ }^{76}$ when it noted that the record goal scorer in the history of the world championships was the Polish-born Miroslaw Klose.

\section{CONCLUSION}

Sports clubs for Polish migrants who arrived in the Ruhr before World War I developed within the conflicted areas of nationalism, ethnicization, and new identity constructions. For this reason Sokół clubs were always more than simply sports clubs. They were the embodiment of the Polish nation, whose state had been destroyed and which continued to exist only as a cultural project. Polish transnational integration transcended the boundaries of the Prussian-German Reich and also affected Polish citizens in the Russian Empire and the Hapsburg Monarchy. The imaginary Poland was constructed from Poles in three empires.

Football clubs in the Ruhr experienced a boom in the interwar years. Some of the clubs also included miners of Polish origin and thus worked as vehicles of assimilation. After World War II a huge number of thirdgeneration migrants pursued careers in football clubs in the Ruhr. Now memories of immigration began to fade or were degraded into folklore legends. Since the I980s more recent waves of Polish immigrants, some of whom have become leading footballers in top clubs and the German national team, have made this history visible once again, turning it into a topic of both academia and broader society.

Research into the history of Polish sport in the Ruhr has shown that its social function can only satisfactorily be described in the context of social change. The myth of sport's (particularly football's) ability to prevail over ethnic conflicts is plausible only if the history of Ruhr Poles is restricted to the time after World War I. The outlined social and demographic changes pushed the Polish minority along the path of assimilation, but after Hitler's seizure of power the Nazis reintroduced repressive measures against the Ruhr's Poles. Accompanied by pseudo-academic attempts to "Germanize" them with the aim of making them "as invisible as possible", ${ }^{77}$ at their most extreme these measures resorted to violently destroying Polish social organizations.

Patterns in the social dynamics of exclusion and inclusion, as well as segregation and assimilation, can also be analysed in comparison (both synchronic and diachronic). For instance, there are clear signs that in the case of Polish immigrants in northern France segregation in their own Polish clubs in the I920s began to give way to assimilation in and through football at the end of the r940s. This also extended to Polish players 
participating at the top level of football in France. ${ }^{78}$ At the same time, diachronic comparison between Polish migration before World War I and Turkish migration into Germany since the I960s reveals similar processes under utterly different historical conditions. ${ }^{79}$

While the majority of Poles were Prussian/German citizens, the Turks who came to work in the Ruhr pits in the I960s were foreign citizens. They also set up their own independent ethnic football clubs. However, in this case it did not take long before Turkish clubs were (not without some conflict) integrated into German football leagues. ${ }^{80}$ This was further underpinned when German policies vis-à-vis immigrants already living in the country started to change around the turn of the twenty-first century (while policies against new immigrants became stricter): diversity, equality before the law, and the possibility of naturalization were now promoted. At the same time, the German Football Association set up a talent-seeking programme aimed at youngsters, which attracted a huge proportion of players from migrant families. ${ }^{81}$ Almost fifty years after the start of Turkish immigration, players with a Turkish background are now being selected in considerable numbers to play for German clubs and the German national team.

The interrelations of sport and migration in the history of the coalmining region of the Ruhr thus point to the basic ambivalence of sport in processes of social change: it can, on the one hand, act as a medium for setting up "we groups" and the development of ethnic, local, and regional identities; on the other hand, it can indeed help in the development of intercultural exchanges and bridges between social and ethnic groups.

\footnotetext{
78. See the article by Marion Fontaine in the present volume. For the dynamics of segregation and exclusion affecting Polish miners in the interwar period in northern France (which were induced to a high degree by both company and state policies), see the article by Philip Slaby in the present volume.

79. See Diethelm Blecking, "Polish Community before the First World War and Present-Day Turkish Community Formation - Some Thoughts on a Diachronistic Comparison", in John Belchem and Klaus Tenfelde (eds), Irish and Polish Migration in Comparative Perspective (Essen, 2003), pp. I 83-197.

80. Ibid., p. 197, and Blecking, Polen-Türken-Sozialisten, pp. 99-107.

8I. See Diethelm Blecking, “'Ethnisch gemischte Teams funktionieren besser': Integration und Inklusion", available at http://www.bpb.de/gesellschaft/sport/bundesliga/I 5590 I/integrationund-inklusion? $\mathrm{p}=$ all; last accessed is July 20 i 5.
} 